\title{
PENGARUH STRATEGI PEMBELAJARAN SAINS TEKNOLOGI MASYARAKAT TERHADAP PEMAHAMAN KONSEP DAN SIKAP PEDULI LINGKUNGAN SISWA KELAS VII MTSN 2 BONDOWOSO
}

\author{
Khairin Nisaq $^{1 *}$, Dinar Maftukh Fajar ${ }^{1)}$ \\ 1) Program Studi Tadris Ilmu Pengetahuan Alam, Fakultas Tarbiyah dan Ilmu Keguruan, IAIN Jember \\ *e-mail: niskhoirin@gmail.com.
}

\begin{abstract}
The preliminary study of this research has found that science learning in MTsN 2 Bondowoso, East Java had the following issues: the average student score for science subjects was still relatively low, student learning activity in the classroom still needed more improvement, and some students had a low environmental care attitude. This was observed from the amount of rubbish still found under the table and according to interviews the students did not yet know how to process the waste. The purpose of this study is to find out the differences of Science, Technology, and Society learning strategy on the conceptual understanding and environmental care attitude for students of grade VII MTsN 2 Bondowoso. This research belonged to a quasi-experimental type with the Nonequivalent Control Group Design. The sample involved consisted of 56 students whom were grouped into the experimental and the control class. The hypothesis test used was $t$ test (independent sample t-test). The data collection techniques used were questionnaires for environmental care attitude, interviews, observations, and tests. From the results of hypothesis testing, it obtained t value for students' conceptual understanding of 8.30 and t table of 2.04, and t value for students' environmental care attitude of 4.62 and $t$ table of 2.04 with a 5\% significant level. This showed a significant difference in the average score of students' conceptual understanding and students' environmental care attitude before and after implementing the Science, Technology, and Society learning strategy.

Keywords: science technology society, conceptual undersranding, environmenral care attitute, environmental knowledge
\end{abstract}

\begin{abstract}
Abstrak
Studi awal penelitian ini telah mendapatkan permasalahan pembelajaran IPA di MTsN 2 Bondowoso, Jawa Timur sebagai berikut: rerata nilai siswa untuk mata pelajaran IPA masih tergolong rendah, keaktifan siswa dalam pembelajaran di kelas masih perlu banyak ditingkatkan, dan beberapa siswa memiliki sikap peduli lingkungan yang masih rendah. Hal ini teramati dari banyaknya sampah yang masih ditemukan di kolong meja dan menurut wawancara siswa belum mengetahui secara langsung bagaimana pengolahan sampah tersebut. Tujuan penelitian ini adalah untuk mengetahui perbedaan penerapan strategi pembelajaran Sains Teknologi Masyarakat terhadap pemahaman konsep dan sikap peduli lingkungan siswa kelas VII MTsN 2 Bondowoso. Penelitian ini berjenis quasi experiment dengan desain Nonequivalent Control Group Design. Sampel siswa yang terlibat berjumlah 56 siswa yang dikelompokkan pada kelas eksperimen dan kelas kontrol. Uji hipotesis yang digunakan adalah uji t (independent sample t-test). Adapun teknik pengumpulan data menggunakan angket sikap peduli lingkungan, wawancara, observasi, dan tes. Dari hasil pengujian hipotesis diperoleh thitung nilai pemahaman konsep siswa sebesar 8,30 dan ttabel sebesar 2,04, serta thitung nilai sikap peduli lingkungan siswa sebesar 4,62 dan ttabel sebesar 2,04 dengan taraf signifikan 5\%. Hal ini menunjukkan bahwa terdapat perbedaan signifikan pada pemahaman konsep dan sikap peduli lingkungan siswa antara sebelum dan setelah mengikuti pembelajaran yang menerapkan strategi pembelajaran Sains Teknologi Masyarakat.

Kata Kunci: Sains teknologi masyarakat, pemahaman konsep, sikap peduli lingkungan, pengetahuan lingkungan
\end{abstract}




\section{PENDAHULUAN}

Pendidikan merupakan salah unsur penting dalam mencetak sumber daya manusia yang berkualitas dalam suatu negara. Dengan bangsa yang cerdas sebuah negara dapat mengembangkan berbagai teknologi yang sesuai dengan era globalisasi saat ini. Untuk mewujudkan hal tersebut, banyak sekali upaya yang dilakukan pemerintah salah satunya dengan pembaruan kurikulum pada tahun 2013. Sebagai konsekuensi dari pelaksanaan kurikulum 2013, siswa dituntut aktif dan dipacu dalam mengembangkan kemampuan berpikir. Pemahaman siswa sangat erat hubungannya dengan kemampuan berpikir, perolehan pengetahuan dan konsep, sehingga untuk mengetahui pemahaman yang diperoleh seseorang dapat dilihat melalui ketepatan konsep yang diutarakan oleh orang tersebut (Suhardi, 2018). Rendahnya kualitas pendidikan banyak terjadi disebabkan kurangnya perhatian guru terhadap kualitas proses pembelajaran (Khusnah, Ibrohim, \& Ghofur, 2015). Oleh karena itu strategi pembelajaran yang digunakan guru sangat berpengaruh terhadap kualitas proses pembelajaran, yang nantinya akan berpengaruh pula pada pemahaman konsep siswa.

Salah satu strategi pembelajaran yang cocok dalam pembelajaran IPA adalah strategi pembelajaran Sains Teknologi Masyarakat. Strategi tersebut sesuai dengan masalah pendidikan yang dihadapi dalam suatu proses pembelajaran saat ini, yakni proses pembelajaran yang lemah dan kurang mengaitkan antara konsep-konsep yang diajarkan di sekolah dengan realitas sehari-hari siswa. Dengan menerapkan strategi Sains Teknologi masyarakat, guru dapat mengembangkan kemampuan berpikir siswa. Sains Teknologi Masyarakat (STM) merupakan suatu pembelajaran yang mengajak siswa untuk mengetahui tentang isu-isu sains dan teknologi yang terjadi di lingkungan masyarakat yang dibahas dalam pembelajaran di kelas (Pangkal, Darmayanti, \& Sabaryat, 2018). Dengan strategi pembelajaran Sains Teknologi Masyarakat (STM), siswa diajak untuk mengembangkan kemampuan berpikir atas masalah yang ada di masyarakat sehingga dapat meningkatkan pemahaman konsep siswa. Selain itu dengan pembelajaran yang membahas permasalahan yang ada di masyarakat siswa akan lebih peka terhadap lingkungannya. Dengan demikian kepedulian siswa terhadap kondisi lingkungan sekitar akan meningkat.

Peranan strategi pembelajaran untuk meningkatkan pemahaman konsep dan sikap peduli lingkungan telah dibuktikan oleh berbagai penelitian. Penelitian Maemunah dan Maryuningsih (2013) mengungkapkan bahwa siswa yang diajar menggunakan model Sains Teknologi Masyarakat memiliki kreativitas, kepedulian yang lebih besar terhadap masyarakat dan lingkungan, lebih mudah mengaplikasikan konsep-konsep untuk kebutuhan masyarakat, dan memiliki kecenderungan ikut berpartisipasi dalam kegiatan menyelesaikan masalah di lingkungannya. Selanjutnya Arrafi (2019) menyimpulkan bahwa terdapat perbedaan yang signifikan pembelajaran yang menggunakan model pembelajaran Sains Teknologi Masyarakat terhadap pemahaman konsep siswa. Dari hasil penelitian di atas dapat disimpulkan bahwa pembelajaran dengan menerapkan strategi Sains Teknologi Masyarakat dapat meningkatkan pemahaman konsep dan sikap peduli lingkungan siswa.

Berdasarkan hasil wawancara dengan salah satu guru IPA di MTsN 2 Bondowoso diketahui bahwa keaktifan siswa dalam pembelajaran IPA di dalam kelas masih rendah. Diketahui pula bahwa proses pembelajaran masih berpusat pada guru dengan dominan pada penyampaian ceramah, tanya jawab, dan pemberian tugas, sehingga siswa kesulitan dalam memahami konsep yang dipelajari pada suatu materi. Hal ini menyebabkan nilai mata pelajaran IPA pada siswa masih banyak yang berada di bawah kriteria ketuntasan minimal (KKM). Misalnya rerata hasil rapor mata pelajaran IPA kelas 7 semester ganjil 2019/2020 sebesar 75. Selain itu, hasil wawancara peneliti dengan siswa menunjukkan bahwa beberapa siswa di MTsN 2 Bondowoso memiliki sikap peduli lingkungan yang masih rendah. Hal ini dapat dilihat dari banyaknya sampah yang masih ditemukan di kolong meja dan belum ada pemilahan dalam membuang sampah di kelas, padahal sekolah telah menyediakan tempat 
sampah yang terpisah antara sampah organik dan non organik. Selain itu ketika ditanyakan mengenai beberapa contoh pengolahan sampah beberapa siswa masih kebingungan dan mengaku belum pernah mempraktikkan secara langsung pengolahan sampah tersebut. Hasil angket siswa terkait sikap peduli lingkungan yang diberikan oleh peneliti juga mengkonfirmasi hal ini, yakni memperoleh rerata skor 137 dari 200 sehingga perlu ditingkatkan.

Dari latar belakang tersebut, peneliti berinisiatif menerapkan strategi pembelajaran Sains Teknologi Masyarakat dengan harapan dapat menjadi solusi untuk meningkatkan sikap peduli lingkungan dan sikap peduli lingkungan siswa. Tujuan dari penelitian ini adalah: (1) mengetahui tingkat pemahaman konsep siswa kelas VII MTsN 2 Bondowoso dengan menggunakan strategi pembelajaran Sains Teknologi Masyarakat (STM) pada materi pencemaran lingkungan, (2) mengetahui ada tidaknya perbedaan penerapan strategi pembelajaran Sains Teknologi Masyarakat (STM) terhadap pemahaman konsep siswa kelas VII MTsN 2 Bondowoso, (3) mengetahui tingkat sikap peduli lingkungan siswa kelas VII MTsN 2 Bondowoso dengan menggunakan strategi pembelajaran Sains Teknologi Masyarakat (STM), (4) mengetahui ada tidaknya perbedaan penerapan strategi pembelajaran Sains Teknologi Masyarakat (STM) terhadap sikap peduli lingkungan siswa kelas VII MTsN 2 Bondowoso.

\section{METODE}

Penelitian ini menggunakan pendekatan kuantitatif yang berjenis penelitian Quasi Experiment (eksperimen semu), di mana terdapat kelompok kontrol dan kelompok eksperimen. Namun, dalam hal ini kelompok kontrol tidak dapat berfungsi sepenuhnya mengontrol variabel-variabel luar yang mempengaruhi pelaksanaan eksperimen (Sugiyono, 2014). Desain yang digunakan adalah Nonequivalent Control Group Design. Sampel diambil dengan teknik purposive sampling dengan melibatkan siswa kelas VII A sebagai kelas eksperimen dan kelas VII B sebagai kelas kontrol dengan jumlah siswa masing-masing 28 orang. Purposive sampling, yaitu teknik penentuan sampel dengan pertimbangan tertentu. Pertimbangan yang dilakukan dalam pengambilan sampel ini, yaitu 2 kelas tersebut diajar oleh guru yang sama dan memiliki kemampuan awal yang sama. Studi awal telah memperoleh data bahwa hasil pretest kedua kelas memiliki kemampuan yang sama, serta sampel terdistribusi normal dan homogen. Untuk melihat pengaruh penerapan strategi pembelajaran Sains Teknologi Masyarakat terhadap pemahaman konsep dan sikap peduli lingkungan siswa, penelitian ini menggunakan uji statistik menggunakan uji t tidak berpasangan (independent sample t-test). Skemanya seperti pada Tabel 1.

Tabel 1 Jenis Penelitian desain Nonequivalent Control Group Design

\begin{tabular}{|l|c|c|c|}
\hline \multicolumn{1}{|c|}{ Kelompok } & Pretest & Perlakuan & Posttest \\
\hline Eksperimen & $\mathrm{O}_{1}$ & $\mathrm{X}$ & $\mathrm{O}_{2}$ \\
\hline Kontrol & $\mathrm{O}_{3}$ & - & $\mathrm{O}_{4}$ \\
\hline
\end{tabular}

Adapun instrumen yang digunakan dalam penelitian ini adalah angket dan soal. Pemberian soal dan angket ini dilakukan sebelum (pretest) dan sesudah (posttest) perlakuan. Sebelum diberikan kepada siswa angket dan soal tersebut telah divalidasi oleh 3 validator. Angket digunakan untuk mengukur sikap peduli lingkungan dan soal digunakan untuk mengukur pemahaman konsep siswa. Angket dalam penelitian ini menggunakan skala likert (sangat setuju, setuju, kurang setuju, tidak setuju, dan sangat tidak setuju). Angket skala likert berjumlah 40 butir yang berbentuk pernyataan yang terdiri dari pernyataan positif (+) dan negatif (-). Setiap butir pernyataan mewakili setiap indikator yang diukur. Kisi-kisi angket tiap indikator dipaparkan pada Tabel 2. 
Tabel 2. Kisi Kisi Instrumen Angket Sikap Peduli Lingkungan

\begin{tabular}{|c|l|c|c|}
\hline \multirow{2}{*}{ No } & \multicolumn{1}{|c|}{ Indikator Sikap Peduli Lingkungan } & \multicolumn{2}{c|}{ Jumlah Pertanyaan } \\
\cline { 3 - 4 } & \multicolumn{1}{|c|}{$\begin{array}{c}\text { Positif } \\
\text { Negatif }\end{array}$} \\
\hline 1 & $\begin{array}{l}\text { Memiliki kesadaran dan rasa syukur atas alam yang } \\
\text { telah dihuni sebagai ciptaan Allah }\end{array}$ & 4 & 4 \\
\hline 2 & $\begin{array}{l}\text { Memiliki rasa ingin tau, kritis dan sikap peduli } \\
\text { lingkungan dalam mencegah dan mengatasi } \\
\text { kerusakan lingkungan }\end{array}$ & 13 & 8 \\
\hline 3 & $\begin{array}{l}\text { Menggunakan secara bijaksana bahan-bahan yang } \\
\text { dapat merusak lingkungan }\end{array}$ & 6 & 5 \\
\hline
\end{tabular}

Data yang diperoleh kemudian diolah dengan uji statistik menggunakan uji $\mathrm{t}$ independent sample t-test, uji ini digunakan untuk melihat ada tidaknya pengaruh penerapan strategi pembelajaran terhadap sikap peduli lingkungan siswa.

Soal yang digunakan untuk mengukur pemahaman konsep siswa berjumlah 20 soal pilihan ganda. Soal yang digunakan ini, disesuaikan dengan indikator pemahaman konsep dan indikator materi. Sebelum digunakan soal dan angket siswa telah di validasi oleh 3 validator ahli, yakni 2 dosen Tadris IPA IAIN Jember yang berkompeten dalam bidang biologi dan kimia dan 1 guru MTsN 2 Bondowoso yang berkompeten pada bidang biologi. Kriteria pemilihan validator didasarkan pada pertimbangan bahwa validator tersebut menguasai materi yang terdapat pada soal dan angket. Pada Tabel 3 ditampilkan kisi-kisi soal berdasarkan indikator pemahaman konsep dan indikator materi.

\section{HASIL DAN PEMBAHASAN}

1) Pemahaman Konsep

Pemberian soal dilakukan sebelum dan setelah pembelajaran berlangsung untuk mengetahui tingkat pemahaman konsep siswa yang menerapkan strategi pembelajaran Sains Teknologi Masyarakat. Adapun hasil pretest dan postest kelas eksperimen tiap indikator pemahaman konsep dapat dilihat pada Gambar 1.

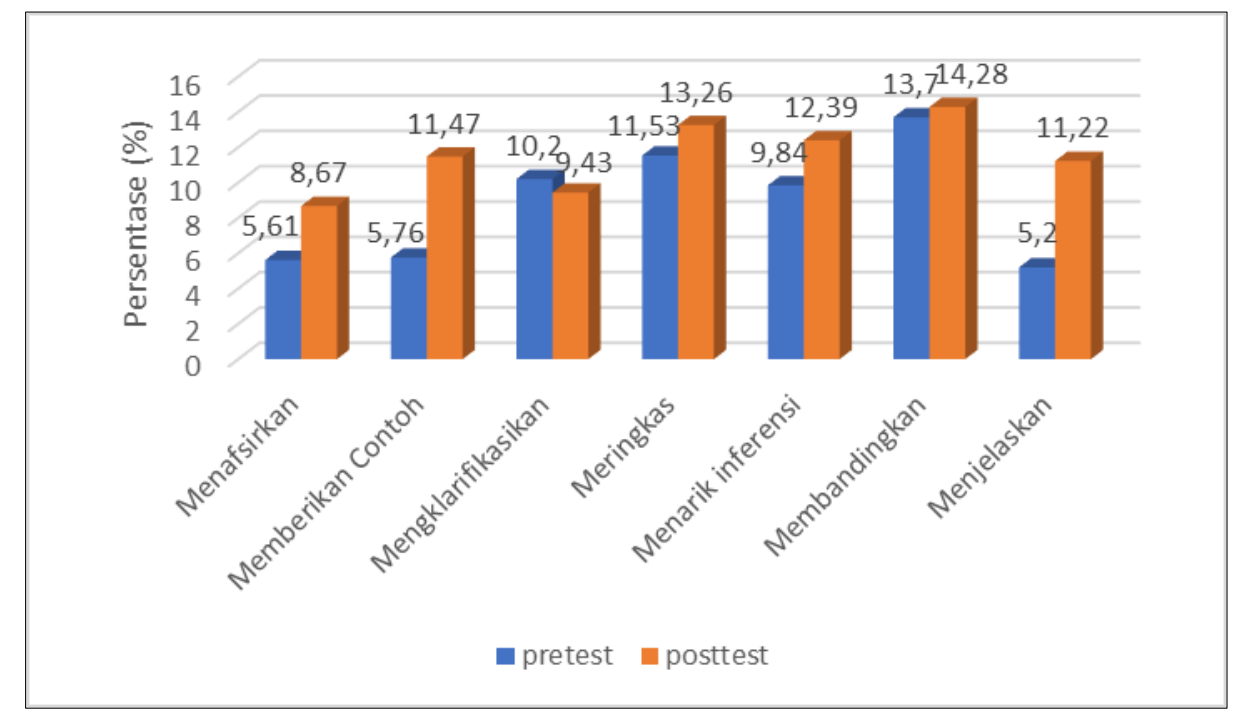

Gambar 1. Diagram Batang Hasil Pemahaman Konsep Kelas Eksperimen 
Gambar 1 menunjukkan bahwa peningkatan pemahaman konsep tertinggi pada indikator memberikan contoh, yakni mengalami peningkatan sebesar $5,71 \%$, sementara terdapat penurunan pemahaman konsep pada indikator mengklasifikasikan sebesar $0,77 \%$. Dari grafik tersebut dapat disimpulkan tingkat kemampuan pemahaman konsep siswa pada tiap indikator pemahaman konsep mengalami peningkatan kecuali pada indikator mengklasifikasikan. Rata-rata peningkatan ini terhitung sebesar 2,70 \%.

Tabel 3. Kisi-kisi Tes Pemahaman Konsep

\begin{tabular}{|c|c|c|c|}
\hline No & $\begin{array}{c}\text { Indikator Pemahaman } \\
\text { Konsep }\end{array}$ & Indikator Materi & $\begin{array}{c}\text { Nomor } \\
\text { Soal }\end{array}$ \\
\hline 1. & $\begin{array}{c}\text { Meringkas } \\
\text { (summarizing) }\end{array}$ & $\begin{array}{l}\text { Menjelaskan pengertian Pencemaran } \\
\text { Lingkungan } \\
\text { Menjelaskan pengertian pencemaran udara } \\
\text { Menjelaskan pengertian pencemaran tanah }\end{array}$ & $1,8,14$ \\
\hline 2. & $\begin{array}{l}\text { Memberikan contoh } \\
\text { (exemplifying) }\end{array}$ & $\begin{array}{l}\text { Menjelaskan macam-macam Pencemaran } \\
\text { Lingkungan } \\
\text { Menjelaskan macam-macam Pencemaran } \\
\text { Lingkungan } \\
\text { Menyelidiki pengaruh air jernih dari tercemar } \\
\text { terhadap kondisi (pergerakan) ikan } \\
\text { Membuat gagasan tertulis tentang bagaimana } \\
\text { mengurangi dampak pencemaran tanah } \\
\text { Membuat gagasan tertulis tentang bagaimana } \\
\text { mengurangi dampak pencemaran tanah } \\
\text { Menjelaskan dampak pencemaran udara }\end{array}$ & $\begin{array}{l}2,3,6 \\
17,18 \\
19\end{array}$ \\
\hline 3. & $\begin{array}{l}\text { Menafsirkan } \\
\text { (interpreting) }\end{array}$ & Menjelaskan pengertian pencemaran air & 4 \\
\hline 4. & $\begin{array}{l}\text { Menjelaskan } \\
\text { (explaining) }\end{array}$ & $\begin{array}{l}\text { Membuat gagasan tertulis tentang bagaimana } \\
\text { mengatasi dan mengurangi pencemaran air } \\
\text { Menjelaskan dampak pencemaran udara } \\
\text { Menjelaskan dampak pencemaran udara } \\
\text { Menjelaskan dampak pencemaran udara }\end{array}$ & $\begin{array}{l}5,11 \\
12,13\end{array}$ \\
\hline 5. & $\begin{array}{l}\text { Menarik inferensi } \\
\quad \text { (inferring) }\end{array}$ & $\begin{array}{l}\text { Membuat gagasan tertulis tentang bagaimana } \\
\text { mengatasi dan mengurangi pencemaran air } \\
\text { Menyebutkan faktor-faktor penyebab } \\
\text { pencemaran udara } \\
\text { Menjelaskan dampak pencemaran tanah }\end{array}$ & $7,9,15$ \\
\hline 6. & $\begin{array}{l}\text { Mengklasifikasikan } \\
\text { (classifying) }\end{array}$ & $\begin{array}{l}\text { Menyelidiki pengaruh air jernih dari tercemar } \\
\text { terhadap kondisi (pergerakan) ikan } \\
\text { Menjelaskan dampak pencemaran tanah }\end{array}$ & 10,16 \\
\hline 7. & $\begin{array}{l}\text { Membandingkan } \\
\text { (comparing) }\end{array}$ & Menjelaskan dampak pencemaran udara & 20 \\
\hline
\end{tabular}

Tingkat pemahaman konsep kelas eksperimen berdasarkan indikator materi dapat dilihat pada Gambar 2. Pada Gambar 2, peningkatan pemahaman konsep tertinggi pada indikator mengurangi dampak pencemaran tanah, yakni mengalami peningkatan sebesar 4,38\%. Dari grafik tersebut dapat disimpulkan tingkat kemampuan pemahaman konsep siswa pada tiap indikator materi mengalami peningkatan. Rata-rata peningkatan pemahaman konsep pada tiap indikator materi terhitung sebesar 1,87\%. 


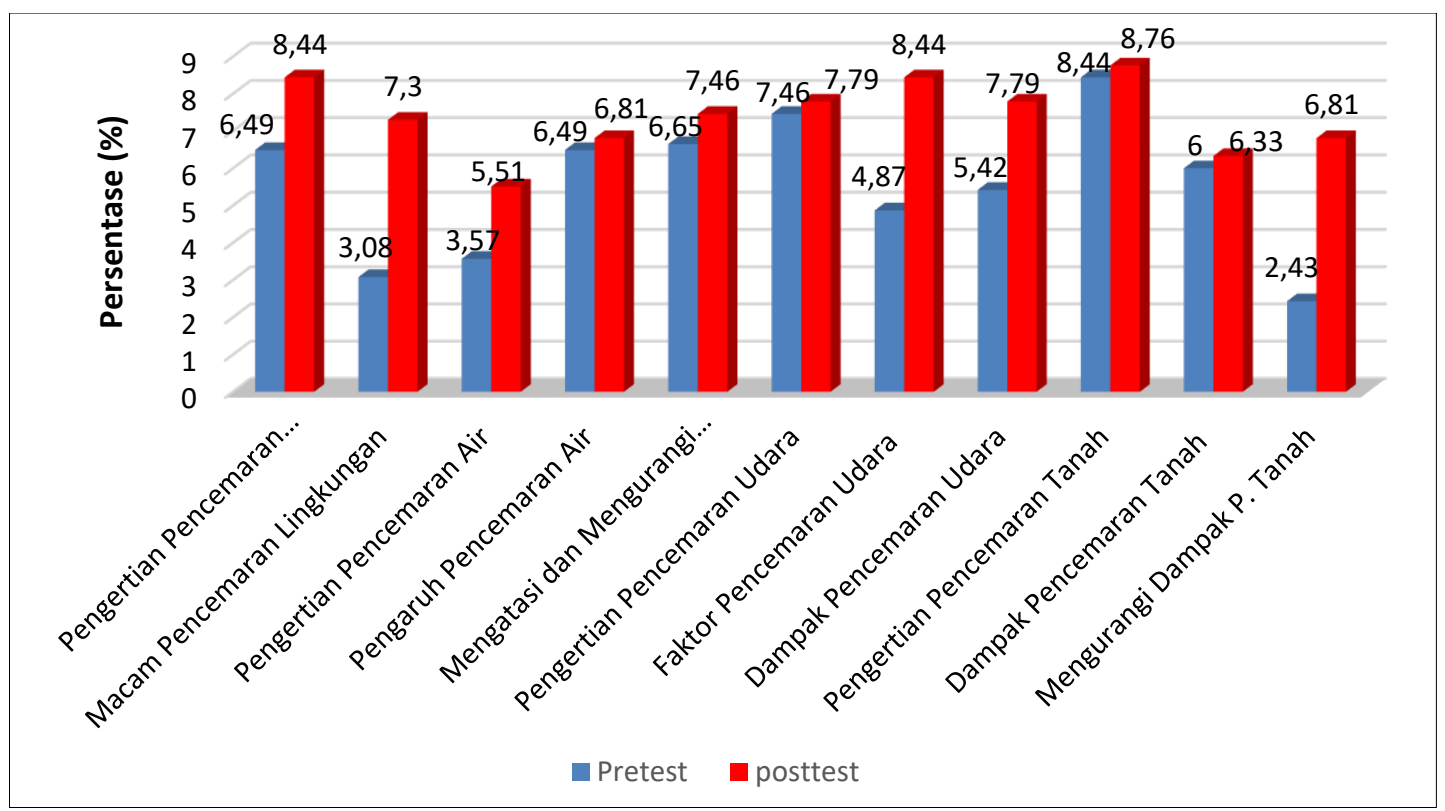

Gambar 2. Diagram Batang Hasil Pemahaman Konsep berdasarkan Indikator Materi

Selanjutnya hasil uji hipotesis dilakukan untuk mengetahui pengaruh penerapan strategi pembelajaran Sains Teknologi Masyarakat terhadap pemahaman konsep siswa. Sebelum dilakukan uji hipotesis, dilakukan uji prasyarat data berupa uji normalitas data dan homogenitas. Setelah diketahui data pemahaman konsep berdistribusi normal, dilanjutkan dengan uji hipotesis. Pengujiannya dilakukan dengan uji independent sample t-test, dengan taraf signifikan $a=0,05$. Hipotesis statistik yang digunakan pada uji hipotesis adalah:

$\mathrm{H}_{\mathrm{a}}$ : Adanya perbedaan yang signifikan penerapan strategi pembelajaran Sains Teknologi Masyarakat (STM) terhadap pemahaman konsep siswa kelas VII MTsN 2 Bondowoso pada materi Pencemaran Lingkungan tahun pelajaran 2020/2021.

$\mathrm{H}_{\mathrm{o}}$ : Tidak adanya perbedaan yang signifikan penerapan strategi pembelajaran Sains Teknologi Masyarakat (STM) terhadap pemahaman konsep siswa kelas VII MTsN 2 Bondowoso pada materi Pencemaran Lingkungan tahun pelajaran 2020/2021.

Tabel 1 Independent Sample T-test Posttest Pemahaman Konsep Kelas Eksperimen dan Kelas Kontrol

\begin{tabular}{|c|c|c|c|c|}
\hline Kelas & Rata-rata & $\mathbf{t}_{\text {hitung }}$ & $\mathbf{t}_{\text {tabel }}$ & Sig. (2-tailed) \\
\hline Eksperimen & 81,79 & 8,303 & 2,048 & 0,000 \\
\hline
\end{tabular}

Berdasarkan kriteria pengujian Independent Sample T-test hasil analisis penelitian ini adalah thitung $>$ tabel, yaitu 8,303 $>2,048$ maka $\mathrm{H}_{\mathrm{a}}$ diterima dan $\mathrm{H}_{\mathrm{o}}$ ditolak. Dapat disimpulkan bahwa terdapat perbedaan yang signifikan kemampuan pemahaman konsep siswa kelas eksperimen dan kelas kontrol. Hal tersebut menunjukkan bahwa penerapan strategi pembelajaran Sains Teknologi Masyarakat berpengaruh terhadap pemahaman konsep siswa.

Penelitian ini mendukung peneliti sebelumnya yaitu penelitiannya oleh Minasari (2017) yang dilakukan di MTs Paradigma Palembang, yang menemukan bahwa pemahaman konsep siswa lebih baik daripada kelas yang menerapkan model pembelajaran konvensional. Paparan hasil penelitian diatas peneliti melakukan penelitian dengan model pembelajaran Sains Teknologi Masyarakat (STM) untuk mengetahui perbedaan pemahaman konsep siswa. Penelitian diatas diperkuat oleh Yusuf (2019) yang 
dilakukan di SMP Negeri 1 Bakongan Aceh Selatan, yang menemukan bahwa terdapat peningkatan pemahaman konsep siswa yang menerapkan model pembelajaran Sains Teknologi Masyarakat.

\section{2) Sikap Peduli Lingkungan}

Pemberian angket dilakukan sebelum dan setelah pembelajaran berlangsung pada untuk mengetahui tingkat sikap peduli lingkungan siswa yang menerapkan strategi pembelajaran Sains Teknologi Masyarakat. Adapun hasilnya dapat dilihat pada Gambar 3.

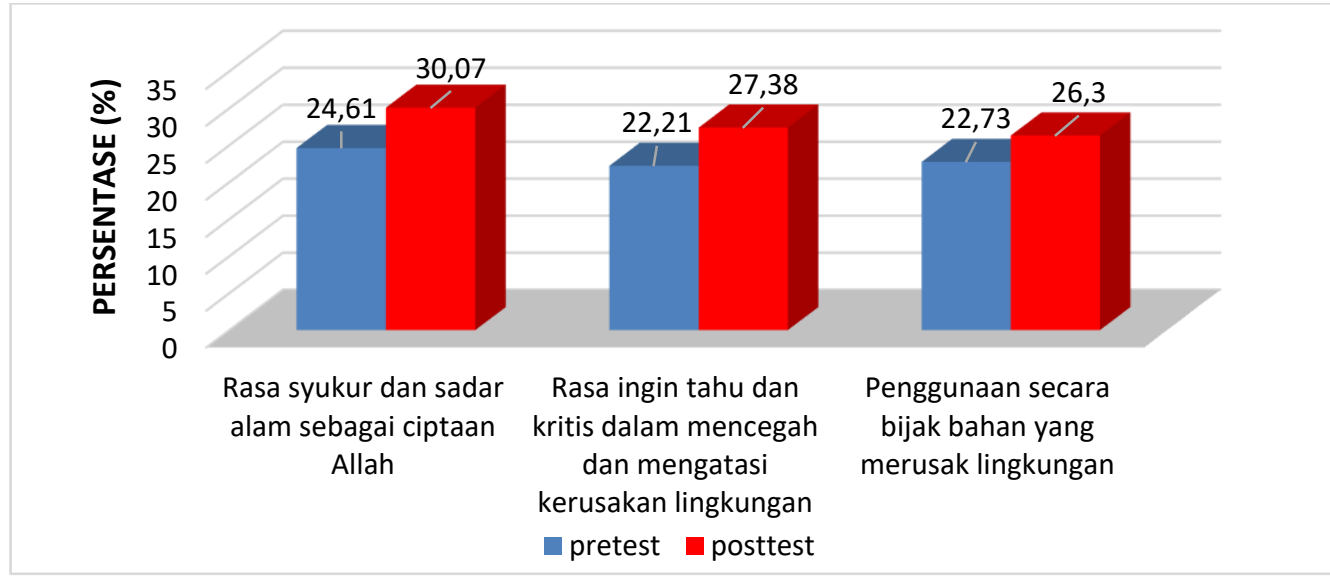

\section{Gambar 3. Diagram Batang Hasil Posttest Sikap Peduli Lingkungan}

Gambar 3 menunjukkan perolehan nilai pretest dan posttest sikap peduli lingkungan kelas eksperimen pada tiap indikator. Peningkatan pemahaman konsep tertinggi pada indikator rasa syukur dan sadar alam sebagai ciptaan Allah yakni mengalami peningkatan sebesar 5,46\%. Dari grafik tersebut dapat disimpulkan tingkat sikap peduli lingkungan siswa pada tiap indikator mengalami peningkatan. Rata-rata peningkatan ini terukur sebesar $4,73 \%$.

Selanjutnya uji hipotesis dilakukan untuk mengetahui pengaruh penerapan strategi pembelajaran Sains Teknologi Masyarakat terhadap sikap peduli lingkungan siswa. Sebelum dilakukan uji hipotesis, dilakukan uji prasyarat data berupa uji normalitas data dan homogenitas. Setelah diketahui data sikap peduli lingkungan berdistribusi normal, dilanjutkan dengan uji hipotesis. Pengujiannya dilakukan dengan uji independent sample ttest, dengan taraf signifikan $a=0,05$. Hipotesis statistik yang digunakan pada uji hipotesis adalah:

$\mathrm{H}_{\mathrm{A}}$ : Adanya perbedaan yang signifikan penerapan strategi pembelajaran Sains Teknologi Masyarakat (STM) terhadap sikap peduli lingkungan pada kelas eksperimen dan kontrol siswa kelas VII MTsN 2 Bondowoso pada materi Pencemaran Lingkungan tahun pelajaran 2020/2021.

$\mathrm{H}_{\mathrm{o}}$ : Tidak adanya perbedaan yang signifikan penerapan strategi pembelajaran Sains Teknologi Masyarakat (STM) terhadap sikap peduli lingkungan pada kelas eksperimen dan kontrol siswa kelas VII MTsN 2 Bondowoso pada materi Pencemaran Lingkungan tahun pelajaran 2020/2021. 


\section{Tabel 4 Independent Sample T-test Posttest Sikap Peduli Lingkungan} Kelas Eksperimen dan Kontrol

\begin{tabular}{|c|c|c|c|c|}
\hline Kelas & Rata-rata & $\mathbf{t}_{\text {hitung }}$ & $\mathbf{t}_{\text {tabel }}$ & Sig. (2-tailed) \\
\cline { 1 - 2 } Eksperimen & 165,64 & 4,620 & 2,048 & 0,000 \\
\cline { 1 - 2 } Kontrol & 154,57 & & & \\
\hline
\end{tabular}

Berdasarkan kriteria pengujian Independent Sample T-test hasil analisis penelitian ini adalah thitung $>$ tabel, yaitu 4,620 > 2,048 maka $\mathrm{H}_{\mathrm{a}}$ diterima dan $\mathrm{H}_{\mathrm{o}}$ ditolak. Dapat disimpulkan bahwa terdapat perbedaan yang signifikan sikap peduli lingkungan siswa kelas eksperimen dan kelas kontrol. Hal tersebut menunjukkan bahwa penerapan strategi pembelajaran Sains Teknologi Masyarakat berpengaruh terhadap sikap peduli lingkungan siswa. Penelitian ini mendukung penelitian sebelumnya yaitu penelitian oleh Fitria (2017) yang menunjukkan bahwa sikap peduli lingkungan siswa kelas eksperimen yang menggunakan pendekatan Sains Teknologi Masyarakat lebih memuaskan daripada kelas kontrol yang tidak menerapkan pendekatan Sains Teknologi Masyarakat.

\section{KESIMPULAN}

Berdasarkan hasil penelitian yang telah dilaksanakan di MTsN 2 Bondowoso, melalui pembelajaran Sains Teknologi Masyarakat, menunjukkan terdapat peningkatan pemahaman konsep dan sikap peduli lingkungan siswa. Selain itu dilihat pada persentase tiap indikator, masing-masing indikator mengalami peningkatan. Peningkatan sikap peduli lingkungan siswa juga dapat terlihat pada sikap siswa yang berinisiatif untuk memanfaatkan sampah plastik di sekolah untuk dijadikan ecobriks. Selain itu, siswa juga mulai mengubah kebiasaan penggunaan botol minum plastik sekali pakai beralih pada botol sehat yang dapat digunakan dalam jangka waktu yang lama. Dampak positif lain yang diperoleh adalah peningkatan motivasi belajar siswa karena penerapan strategi pembelajaran Sains Teknologi Masyarakat ini dilaksanakan dengan melibatkan siswa secara aktif dengan penyajian yang menyenangkan (Abdillah \& Fajar, 2020).

Saran yang ingin coba peneliti sampaikan berikut dapat dijadikan masukan atau bahan pertimbangan untuk penelitian selanjutnya. Penelitian selanjutnya bisa memaparkan mengenai variabel-variabel lain yang bisa diketahui peningkatannya melalui pembelajaran Sains Teknologi Masyarakat. misalnya mengenai kemampuan berfikir kritis siswa yang diajarkan melalui pembelajaran Sains Teknologi Masyarakat, kreativitas siswa dan efektivitas pembelajaran Sains Teknologi Masyarakat dalam mengembangkan minat belajar siswa.

\section{DAFTAR PUSTAKA}

Abdillah, A., \& Fajar, D. M. (2020). Peningkatan Motivasi Belajar Siswa di Kelas VIII SMP Negeri 1 Ajung Melalui Praktikum GLB dan GLBB. EKSAKTA : Jurnal Penelitian dan Pembelajaran MIPA, 5(1), 48-54.

Arraafi, L. (2019). Pengaruh Model Sains Teknologi Masyarakat (STM) Dan Sikap Kepedulian Lingkungan terhadap Pemahaman Konsep IPA. Skripsi Universitas Islam Negeri Raden Intan Lampung.

Fitria, Q. E. (2017). Pengaruh Pendekatan Sains Teknologi Masyarakat (STM) terhadap Sikap Peduli Lingkungan. Tesis Universitas Pendidikan Indonesia.

Khusnah, L., Ibrohim, \& Ghofur, A. (2015). Pengembangan Perangkat Pembelajaran IPA Terpadu Berbasis Salingtemas dan Inkuiri Terbimbing untuk Membentuk Pemahaman Terintegrasi Peserta Didik SMP. Jurnal Pendidikan Sains, 149. 
Maemunah, M. S., \& Maryuningsih, Y. (2013). Penerapan Model Sains Teknologi Masyarakat (STM) pad Pokok Bahasan Pencemaran Lingkungan untuk Meningkatkan Kreativitas Siswa Kelas X di MAN 2 Cirebon. Sciantiae Educatia.

Minasari, U. (2017). Pengaruh Model Pembelajaran Sains Teknologi masyarakat (STM) terhadap Kemampuan Pemahaman Konsep Siswa pada Pokok Bahasan Ekosistem Kelas VII MTS Paradigma Palembang. Skripsi UIN Raden Fatah.

Pangkal, F., Darmayanti, N. W., \& Sabaryat, J. (2018). Pengaruh model Pembelajaran Sains Teknologi Masyarakat terhadap Pemahaman Konsep Siswa Kelas XI IPA pada Mata Pelajaran Fisika Materi Sumber Arus di SMA Katolik Kesuma Mataram Tahun Pelajaran 2017/2018. Orbita. Jurnal Hasil Kajian, Inovasi, dan Aplikasi Pendidikan Fisika, 27.

Sugiyono. (2014). Metode Penelitian Kuantitatif, Kualitatif dan R \& D. Bandung: Alfabeta.

Suhardi, A. (2018). Pengaruh Penggunaan Mind Map Terhadap Pemahaman Konsep Pendidikan Agama Islam Bagi Mahasiswa Iain Jember. Indonesian Journal of Islamic Teaching, 34.

Yusuf, R. I. (2019). Pengaruh Model Sains Teknologi Masyarakat terhadap Pemahaman Konsep Peserta Didik pada MateriI Gerak dan Gaya Kelas VIII di SMP Negeri 1 Bakongan Aceh Selatan. Skripsi UIN Ar-Raniry. 